\title{
Evaluasi Pembelajaran PJOK Berbasis Daring Terhadap Tingkat Pemahaman Dan Motivasi Belajar Siswa Kelas IV - VI SD Negeri Betro, Sedati - Sidoarjo
}

\author{
${ }^{1}$ Danang Ramadhani, ${ }^{2}$ I Made Sriundy Mahardika, ${ }^{3}$ Nanik Indahwati \\ ${ }^{123}$ Program Studi Pendidikan Olahraga, Program Pascasarjana Universitas Negeri Surabaya
} Email: danangramadhani.dr@gmail.com

\begin{abstract}
Abstrak: Penelitian ini bertujuan untuk menganalisa tentang : perencanaan, penataan, implementasi, dan hasil program pembelajaran Pendidikan Jasmani Olahraga dan Kesehatan (PJOK) berbasis daring di SD Negeri Betro, Sedati, Sidoarjo dengan menggunakan model evaluasi CIPP (Context, Input, Process, Product). Subyek penelitian ini adalah Kepala Sekolah, Guru Kelas, Guru PJOK, dan Siswa kelas IV-IV SD Negeri Betro, Sedati - Sidoarjo. Pengumpulan data menggunakan wawancara, angket dan dokumentasi. Analisis data menggunakan analisa deskriptif kuantitatif. Hasil evaluasi menunjukkan bahwa : (1) aspek perencanaan program dengan indikator relevansi kurikulum 2013 dan SE Kemendikbud No. 15 Tahun 2020 dengan pembelajaran di sekolah pada standar kategori sangat baik; aspek penataan program dengan indikator latar belakang guru PJOK dan keterlibatan siswa, serta sarana dan prasarana pada standar kategori sangat baik; aspek implementasi program dengan indikator persiapan dan pelaksanaan pembelajaran PJOK pada standar kategori sangat baik; dan (4) aspek hasil program indikator motivasi belajar menunjukkan motivasi belajar siswa faktor intrinsik dan ekstrinsik menunjukkan kriteria sangat tinggi dan tingkat pemahaman siswa yang dilihat dari hasil belajar siswa menunjukkan nilai lulus KKM.
\end{abstract}

Kata Kunci: Pembelajaran Daring, Evaluasi, CIPP, Motivasi dan Tingkat pemahaman

\section{PENDAHULUAN}

Pandemi Corona virus disease (Covid19) telah menyebar ke banyak negara dan wilayah termasuk Indonesia. Covid-19 ditularkan melalui kontak langsung dengan cairan nafas yang dihasilkan melalui batuk dan bersin orang terinfeksi dan/atau saat menyentuh permukaan yang terkontaminasi virus, kemudian menyentuh area wajah (misal: mata, hidung, dan mulut) (WHO, 2020). Penting bagi masyarakat luas termasuk dunia pendidikan untuk mengambil tindakan pencegahan penularan lebih lanjut, mengurangi dampak wabah dan mendukung tindakan pengendalian.

Perlindungan terhadap anak-anak dan fasilitas pendidikan mejadi hal yang sangat penting. Diperlukan tindakan untuk mencegah potensi penularan dan penyebaran Covid-19 di lingkungan sekolah dengan tetap memberikan kesempatan siswa untuk belajar, dan membangun jiwa siswa yang lebih peduli terhadap sekitar. Siswa juga harus mendapatkan informasi dan fakta tentang Covid-19 secara benar sehingga membantu mengurangi ketakutan dan kecemasan siswa serta membangun kemampuan siswa untuk mengatasi dampak sekunder dari penyakit ini.

Dalam usaha pemenuhan hak peserta didik untuk mendapatkan layanan pendidikan selama darurat penyebaran Covid-19, Kementerian Pendidikan Republik Indonesia melalui Surat Edaran (SE) Nomor 4 Tahun 2020 tentang Pelaksanaan Kebijakan Pendidikan dalam Masa Darurat Penyebaran Covid-19 mengeluarkan kebijakan untuk penyelenggaraan proses pembelajaran Belajar dari Rumah. Program Belajar dari Rumah (BDR) pada Tahun Ajaran 2019/2020 dilaksanakan melalui pembelajaran daring/jarak jauh, menitikberatkan pada pengalaman belajar yang bermakna bagi siswa, tanpa tuntutan menuntaskan seluruh capaian kurikulum untuk kenaikan kelas maupun kelulusan. Program BDR fokus pada pendidikan kecakapan hidup, antara lain mengenai pandemi Covid-19.

Seiring dengan perkembangan pandemi Covid-19 dan dimulainya tahun ajar baru 2020/2021 Kementrian Pendidikan dan Kebudayaan melalui SE Nomor 15 Tahun 2020 menetapkan untuk tetap melaksanakan 
program BDR melalui pembelajaran jarak jauh daring dan/atau luring. Maka dengan ini, pihak sekolah termasuk SD Negeri Betro, Sedati, Sidoarjo melakukan perubahan proses pembelajaran tatap muka menjadi proses pembelajaran jarak jauh berbasis daring.

Pendidikan Jasmani Olahraga dan Kesehatan (PJOK) merupakan mata pelajaran wajib pada kurikulum pendidikan dasar dan menengah wajib yang tertuang pada UU Nomor 20 Tahun 2003 tentang Sistem Pendidikan Nasional yang menerangkan "kelompok mata pelajaran jasmani, olahraga, dan kesehatan pada SD/MI/SDLB/ Paket A, SMP/MTs/SMPLB/Paket

$\mathrm{B}$, SMA/MA/SMALB/ Paket C, SMK/ MAK atau bentuk lain yang sederajat dilaksanakan melalui kegiatan pendidikan jasmani, olahraga, pendidikan kesehatan, ilmu pengetahuan alam, dan muatan lokal yang relevan".

Maka kegiatan pembelajaran PJOK dalam Masa Darurat Penyebaran Covid-19 tetap wajib dilaksanakan dengan menggunakan sistem daring. Dalam pelaksanaan pembelajaran PJOK dengan sistem tatap muka, daring maupun luring tetap harus mengacu pada muatan tujuan pendidikan yang tertuang pada Permendiknas Nomor 22 Tahun 2006. Tujuan pendidikan yang dimaksud meliputi: mengembangkan keterampilan pengelolaan diri dalam upaya pengembangan dan pemeliharaan kebugaran jasmani serta pola hidup sehat melalui berbagai aktivitas jasmani dan olahraga yang terpilih.

Pembelajaran PJOK menjadi penting pada masa pandemi ini. Pembatasan Sosial Berskala Besar dan penutupan kegiatan sekolah secara tatap muka membuat terganggunya seluruh kegiatan fisik rutin siswa. Oleh karena itu ketika sekolah mulai kembali dibuka secara daring, memberikan kesempatan bagi siswa untuk kembali aktif melakukan kegiatan fisik sehari- hari termasuk saat pembelajaran PJOK. Pembelajaran PJOK memulihkan kembali kegiatan fisik secara teratur dan dapat membantu siswa pulih dari stres serta kecemasan yang mereka alami selama pandemi Covid-19 (Chen, et al. 2020)

Masa pandemi di Tahun ajaran baru
2020/2021 SD Negeri Betro, Sedati, Sidoarjo menerapkan program Belajar dari Rumah berbasis daring/jarak jauh. Pembelajaran Jarak Jauh (PJJ) telah disebut dalam UU Nomor 20 Tahun 2003 yang berbunyi "pendidikan jarak jauh adalah pendidikan yang peserta didiknya terpisah dari pendidik dan pembelajarannya menggunakan berbagai sumber belajar melalui teknologi komunikasi, informasi, dan media lain" (Kemendikbud, 2003).

PJJ sendiri baru pertama kali diterapkan di SD Negeri Betro, Sedati Sidoarjo pada Tahun ajaran 2020/2021. Oleh sebab itu masih ditemui kendala-kendala dalam mencapai prestasi belajar yang optimal. Prestasi belajar ditentukan oleh banyak faktor, namun yang menjadi perhatian adalah tingkat pemahaman dan motivasi belajar siswa. Purwanto (2013) mengungkapkan bahwa pemahaman (comprehension) adalah tingkat kemampuan seseorang untuk memahami arti atu konsep, situasi serta fakta yang diketahuinya. Siswa dikatakan memahami sesuatu apabila bisa memberikan penjelasan atau memberi uraian yang lebih rinci tentang hal yang dipelajari dengan menggunakan bahasanya sendiri.

Motivasi menurut Hamalik (2005) adalah suatu perubahan energi dalam diri seseorang dengan timbulnya perasaan dan reaksi untuk mencapai tujuan. Motivasi mendorong seseorang melakukan sesuatu untuk mencapai tujuan yang ingin dicapainya. Motivasi belajar adalah kebutuhan mendasar bagi siswa untuk mencapai prestasi yang tinggi. Untuk mengetahui tingkat keberhasilan metode PJJ berkaitan dengan tingkat pemahaman dan motivasi belajar siswa maka diperlukan evaluasi.

Evaluasi adalah kegiatan atau proses menilai sesuatu (Sudijono, 2007). Melalui evaluasi, guru dapat mengetahui tingkat keberhasilan proses PJJ. Keberhasilan PJJ oleh banyak faktor antara lain: guru, siswa, sarana prasarana, metode, dan lingkungan yang mendukung. Jika salah satu komponen tersebut belum bekerja secara optimal maka akan mempengaruhi program pembelajaran PJOK dalam mencapai tujuannya.

Berdasarkan uraian tersebut, maka diperlukan evaluasi dalam pelaksanaan PJJ 
mata pelajaran PJOK terkait tingkat pemahaman dan motivasi siswa kelas IV-VI SD Negeri Betro, Sedati, Sidoarjo. Model evaluasi yang digunakan dalam penelitian ini adalah CIPP (Context, Input, Process, dan Product). Model CIPP dinilai sesuai dan hasilnya bersifat komprehensif. Aspek CIPP dapat membantu pengambil keputusan untuk menjawab empat pertanyaan dasar mengenai: 1) yang harus dilakukan, 2) cara pelaksanaannya, 3) apakah dilakukan sesuai rencana, 4) hasil dari program.

\section{METODE}

Jenis penelitian yang digunakan dalam penelitian ini adalah penelitian evaluatif. Kegiatan evaluasi betujuan untuk mendapatkan informasi apakah suatu program telah dirancang dengan tepat, telah disesuaikan dengan perencanaan, dan telah mencapai tujuan-tujuan sesuai dengan dengan standar atau kriteria yang sudah ditentukan (Sriundy, 2015). Penelitian ini menggunakan model evaluasi CIPP (Context Input Process Product) yang dikembangkan oleh Stufflebeam. Evaluasi CIPP adalah proses penggambaran, penemuan, penyediaan informasi deskriptif, pertimbangan tentang nilai dan manfaat dari beberapa tujuan yang telah direncanakan, diimplementasikan, dan pengaruhnya untuk membimbing sebuah keputusan, menilai akuntabilitas, dan memahami fenomena (Mulyatiningsih, 2012). Pemilihan model evaluasi CIPP didasarkan atas kelengkapan tahapan dalam mengevaluasi program ajar PJOK.

Fokus yang ada pada penelitian ini yaitu tingkat pemahaman dan motivasi belajar siswa dengan program ajar PJOK berbasis daring pada siswa kelas IV - VI SD Negeri Betro, Sedati, Sidoarjo. Penelitian ini dilakukan dalam beberapa tahap, meliputi: evaluasi context, evaluasi input, evaluasi proses, dan evaluasi produk. Evaluasi context dilakukan untuk melihat kembali pertimbangan- pertimbangan yang dijadikan dasar sebuah program diusulkan. Evaluasi input dilakukan untuk mempelajari apakah perencanaan program telah mempertimbangkan sumber daya yang tersedia. Evaluasi proses dilakukan untuk mempelajari apakah program sudah dilakukan sesuai dengan rencana. Evaluasi produk dilakukan untuk mengetahui apakah program telah tercapai dengan baik, dalam penelitian ini parameter yang ingin dilihat adalah tingkat pemahaman siswa dan motivasi belajar siswa

Penelitian dilaksanakan di SD Negeri Betro, Sedati, Sidoarjo. Waktu penelitian selama 12 minggu dimulai bulan Agustus November 2020. SD Negeri Betro merupakan lembaga pendidikan sekolah dasar, beralamatkan di Jln. Garuda No. 74, Betro, Kecamatan Sedati, Kabupaten Sidoarjo, Provinsi Jawa Timur. Sekolah ini menerapkan Kurikulum 2013 dalam pembelajarannya. SD Negeri Betro merupakan salah satu yang menerapkan pembelajaran jarak jauh melalui program Belajar Dari Rumah (BDR) berbasis daring. Penelitian evaluasi pembelajaran PJOK berbasis daring melibatkan kepala sekolah, guru kelas, guru PJOK dan siswa kelas IV - IV SD Negeri Betro. Rincian informan seperti pada Tabel 1.

Tabel 1. Informan Penelitian

\begin{tabular}{|l|c|c|c|}
\hline \multicolumn{1}{|c|}{ Instrumen } & Jabatan & $\begin{array}{c}\text { Jenis } \\
\text { Kelamin }\end{array}$ & Usia \\
\hline Wawancara & Kepala Sekolah & Laki-laki & 59 \\
\hline \multirow{4}{*}{$\begin{array}{l}\text { Angket Evaluasi } \\
\text { Context, Input, } \\
\text { Process }\end{array}$} & Kepala Sekolah & Laki-laki & 59 \\
\cline { 2 - 4 } & Guru Kelas IV & Perempuan & 36 \\
\cline { 2 - 4 } & Guru Kelas IV & Perempuan & 40 \\
\cline { 2 - 4 } & Guru Kelas V & Perempuan & 46 \\
\cline { 2 - 4 } & Guru Kelas VI & Perempuan & 51 \\
\hline \multirow{2}{*}{$\begin{array}{l}\text { Angket Evaluasi } \\
\text { Product }\end{array}$} & $\begin{array}{c}\text { Gelas IV - VI } \\
\text { (83 Siswa) }\end{array}$ & Laki-laki & $9-12$ \\
\cline { 2 - 3 } & Perempuan & \\
\hline \multirow{2}{*}{ Dokumentasi } & Guru PJOK & Laki-laki & 31 \\
\cline { 2 - 4 } & Guru PJOK & Laki-laki & 26 \\
\hline
\end{tabular}

Kepala sekolah bertindak sebagai informan kunci pada penelitian ini sekaligus sebagai salah satu narasumber untuk evaluasi context, input dan process. Guru kelas bertindak sebagai narasumber untuk evaluasi context, input dan process. Penelitian ini menggunakan siswa sebagai acuan evaluasi product. Produk yang akan diukur meliputi hasil belajar dan tingkat motivasi siswa.

Peneliti mengambil siswa kelas IV - IV dikarenakan siswa kelas IV diperkirakan telah 
terakreditasi Peringkat 4 (No. SK: 36/E/KPT/2019)

mampu memahami pengertian secara kompleks. Anak- anak lebih mudah diatur dan memahami instruksi dari peneliti sehingga memudahkan dalam pengumpulan data. Siswa kelas IV - VI SD Negeri Betro, Sedati, Sidoarjo. Populasi siswa dalam penelitian ini berjumlah 162 yang terdiri dari 2 kelas IV, 2 kelas V, dan 2 kelas VI. Rincian kelas dapat dilihat dari Tabel 2.

Tabel 2. Rincian Kelas

\begin{tabular}{|c|c|c|c|c|c|c|}
\hline \multirow{2}{*}{ No. } & \multicolumn{2}{|c|}{ Kelas IV } & \multicolumn{2}{c|}{ Kelas V } & \multicolumn{2}{c|}{ Kelas VI } \\
\cline { 2 - 7 } & Kelas & $\sum$ siswa & Kelas & $\sum$ siswa & Kelas & $\sum_{\text {siswa }}$ \\
\hline 1 & A & 26 & A & 28 & A & 27 \\
\hline 2 & B & 28 & B & 27 & B & 26 \\
\hline \multicolumn{2}{|c|}{ Jumlah } & 54 & Jumlah & 55 & Jumlah & 53 \\
\hline
\end{tabular}

Tehnik pengamblan sampel menggunakan purposive sampling dengan kriteria yang telah ditetapkan berdasarkan tujuan penelitian (Sriundy, 2015). Kriteria dari sampel penelitian ini adalah guru penanggung jawab sekolah dan kelas IV - VI, siswa kelas IV - VI. Masing-masing tingkatan kelas hanya diambil satu kelas dengan jumlah siswa terbanyak dari masing- masing tingkatan kelas. Siswa yang terlibat pada penelitian terdiri dari kelas IV (28 siswa), kelas V (28 siswa), dan kelas VI (27siswa). Keseluruhan siswa terdiri dari 44 siswa lakilaki dan 39 siswa perempuan. Bisa dikatakan bahwa berdasarkan jenis kelamin siswa memiliki proporsi yang tidak berbeda jauh. Rentang usia siswa antara 9 tahun hingga 12 tahun.

Teknik pengumpulan data pada penelitian ini dengan metode wawancara, angket dan dokumentasi. Metode tersebut digunakan untuk memperoleh komponenkomponen data dalam proses evaluasi. Instrumen yang digunakan dalam penelitian ini terdiri dari pedoman wawancara, lembar pengamatan dokumentasi, dan lembar observasi. Intrumen, sumber data, dan teknik pengambilan data disajikan pada Tabel 3.
Tabel 3. Kisi-kisi instrumen dan teknik pengambilan data

\begin{tabular}{|c|c|c|c|c|}
\hline Evaluasi & Indikator & Sumber data & Metode & Instrumen \\
\hline Context & $\begin{array}{c}\text { Relevansi } \\
\text { materi }\end{array}$ & \begin{tabular}{|c|} 
Kepala \\
Sekolah, Guru \\
Kelas
\end{tabular} & $\begin{array}{c}\text { Wawancara } \\
\text { Angket }\end{array}$ & $\begin{array}{c}\text { Pedoman } \\
\text { wawancara } \\
\text { Lembar } \\
\text { Angket }\end{array}$ \\
\hline \multirow[t]{2}{*}{ Input } & \begin{tabular}{|c|} 
Latar Belakang \\
Guru Penjas \\
dan \\
Keterlibatan \\
Siswa
\end{tabular} & \begin{tabular}{|c|} 
Kepala \\
Sekolah, Guru \\
Kelas
\end{tabular} & $\begin{array}{c}\text { Wawancara } \\
\text { Angket }\end{array}$ & $\begin{array}{l}\text { Pedoman } \\
\text { wawancara } \\
\text { Lembar } \\
\text { Angket }\end{array}$ \\
\hline & $\begin{array}{l}\text { Sarana dan } \\
\text { prasarana } \\
\text { Penjas }\end{array}$ & \begin{tabular}{|c|} 
Kepala \\
Sekolah, Guru \\
Kelas
\end{tabular} & $\begin{array}{c}\text { Wawancara } \\
\text { Angket }\end{array}$ & $\begin{array}{c}\text { Pedoman } \\
\text { wawancara } \\
\text { Lembar } \\
\text { Angket }\end{array}$ \\
\hline Process & $\begin{array}{c}\text { Proses } \\
\text { persiapan dan } \\
\text { pelaksanaan } \\
\text { pembelajaran } \\
\text { Penjas }\end{array}$ & \begin{tabular}{|c|} 
Kepala \\
Sekolah, Guru \\
Kelas
\end{tabular} & $\begin{array}{c}\text { Wawancara } \\
\text { Angket }\end{array}$ & $\begin{array}{c}\text { Pedoman } \\
\text { wawancara } \\
\text { Lembar } \\
\text { Angket }\end{array}$ \\
\hline Product & $\begin{array}{l}\text { Hasil Prestasi } \\
\text { Belajar Siswa }\end{array}$ & $\begin{array}{c}\text { Tingkat } \\
\text { pemahaman } \\
\text { siswa, } \\
\text { Motivasi } \\
\text { belajar siswa }\end{array}$ & $\begin{array}{c}\text { Angket, } \\
\text { Dokumentas } \\
\mathrm{i}\end{array}$ & $\begin{array}{l}\text { Lembar Agket. } \\
\text { Rekap Nilai }\end{array}$ \\
\hline
\end{tabular}

Teknik analisis data yang digunakan adalah analisis deskriptif kuantitatif, untuk kemudian dapat ditarik suatu kesimpulan. Penghitungan statistik deskriptif menggunakan statistik deskriptif persentase dengan penyajian data melalui grafik dan diagram. Cara perhitungan analisis data mencari besarnya frekuensi relatif persentase. Langkah-langkah analisis data yang telah terkumpul yaitu: (1) penskoran hasil angket; (2) menjumlahkan skor total masing-masing aspek; (3) mengelompokkan skor yang didapat berdasarkan tingkat kecenderungan; dan (4) melihat presentase tiap kecenderungan dengan kategori yang ada, sehingga diperoleh informasi mengenai hasil penelitian.

\section{HASIL DAN PEMBAHASAN}

Evaluasi perencanaan program berkaitan dengan pertimbangan yang dijadikan dasar sebuah program. Indikator yang digunakan dalam penelitian ini adalah relevansi materi pembelajaran PJOK berbasis daring dengan Kurikulum 2013 dan SE Kemendikbud Nomor 15 Tahun 2020. Evaluasi perencanaan program dalam penelitian ini masuk ke dalam evaluasi context. Hasil evaluasi context ditunjukkan pada tabel berikut. 
Jurnal Ilmiah Mandala Education

http://ejournal.mandalanursa.org/index.php/JIME/index terakreditasi Peringkat 4 (No. SK: 36/E/KPT/2019)

Tabel 4. Hasil Evaluasi Context

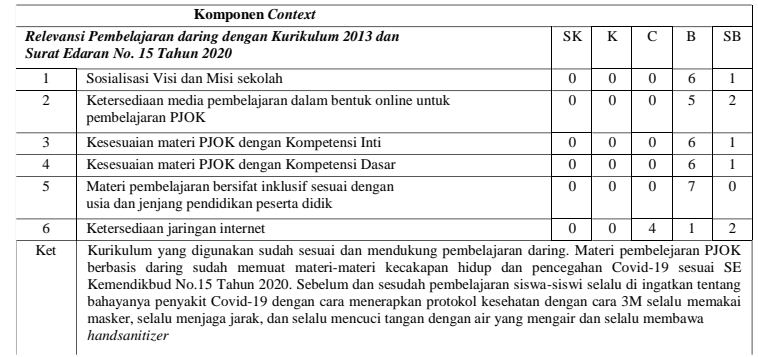

Data evaluasi context tersebut di kategorikan berdasarkan interval nilai seperti pada Tabel 5.

Tabel 5. Pengkategorian data evaluasi konteks

\begin{tabular}{|c|c|c|l|}
\hline No & Interval Perolehan Nilai & Frekuensi & \multicolumn{1}{|c|}{ Keterangan } \\
\hline 1 & $76 \%$ hingga $100 \%$ & 5 & Sangat Baik \\
\hline 2 & $56 \%$ hingga $75 \%$ & 0 & Standar Baik \\
\hline 3 & $40 \%$ hingga 55\% & 0 & Kategori cukup \\
\hline 4 & $<40 \%$ & 0 & Kurang \\
\hline
\end{tabular}

Pengkategorian data evaluasi konteks adalah dominan Sangat Baik dengan frekuensi 5. Hasil evaluasi perencanaan program pembelajaran PJOK berbasis daring adalah "Sangat Baik."

Evaluasi penataan program dilakukan untuk mengetahui apakah perencanaan program telah mempertimbangkan sumber daya yang tersedia dalam pembelajaran PJOK berbasis daring. Terdapat dua indikator yang digunakan yaitu latar belakang guru dan keterlibatan siswa serta sarana dan prasarana yang mendukung proses pembelajaran. Evaluasi penataan program dapat dilihat dari hasil evaluasi input. Hasil evaluasi input seperti pada Tabel 6 .

Tabel 6. Hasil Evaluasi Input

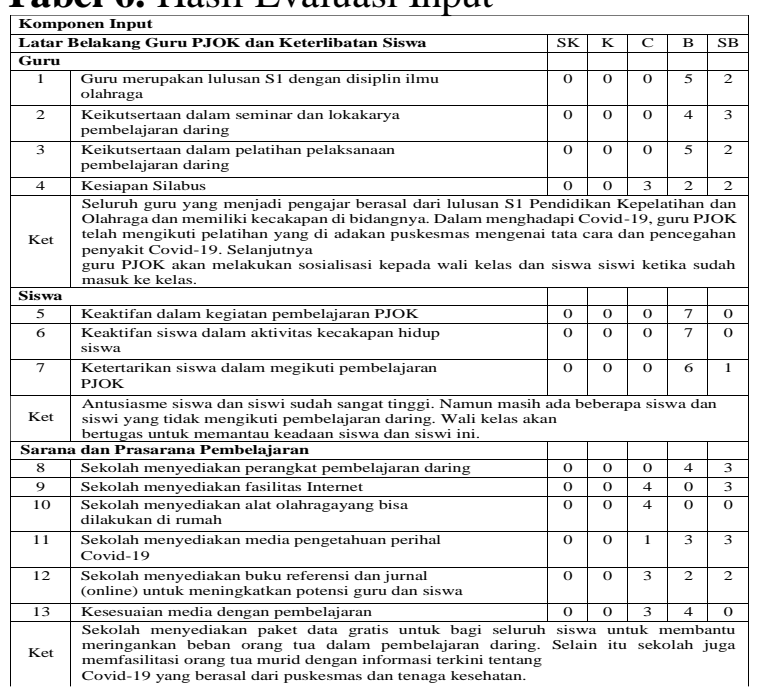

Data evaluasi input indikator latar
Vol. 7. No. 1. Januari 2021

p-ISSN: 2442-9511 e-ISSN: 2656-5862

belakang PJOK dan keterlibatan siswa tersebut di kategorikan berdasarkan interval nilai seperti Tabel 7.

Tabel 7. Pengkategorian data evaluasi input indikator latar belakang guru PJOK dan keterlibatan siswa

\begin{tabular}{|c|c|c|l|}
\hline No & $\begin{array}{c}\text { Interval Perolehan } \\
\text { Nilai }\end{array}$ & Frekuensi & Keterangan \\
\hline 1 & $76 \%$ hingga 100\% & 7 & Sangat Baik \\
\hline 2 & $56 \%$ hingga 75\% & 0 & Standar Baik \\
\hline 3 & $40 \%$ hingga 55\% & 0 & $\begin{array}{l}\text { Kategori } \\
\text { cukup }\end{array}$ \\
\hline 4 & $<40 \%$ & 0 & Kurang \\
\hline
\end{tabular}

Berdasarkan data pengkategorian evaluasi input indikator latar belakang guru PJOK dan keterlibatan siswa didapat nilai dominan Sangat Baik dengan frekuensi 7. Hasil evaluasi penataan program pembelajaran PJOK berbasis daring indikator latar belakang guru PJOK dan keterlibatan siswa adalah "Sangat Baik".

Indikator evaluasi input yang kedua adalah sarana dan prasarana. Berdasarkan hasil angket yang diisikan oleh guru Kelas dilakukan pengkategorian berdasarkan interval nilai seperti pada Tabel 8 .

Tabel 8. Pengkategorian data

evaluasi input indikator sarana dan

\begin{tabular}{|c|c|c|c|}
\hline No & $\begin{array}{c}\text { Interval } \\
\text { Perolehan Nilai }\end{array}$ & Frekuensi & Keterangan \\
\hline 1 & $76 \%$ hingga $100 \%$ & 4 & Sangat Baik \\
\hline 2 & $56 \%$ hingga $75 \%$ & 1 & $\begin{array}{l}\text { Standar } \\
\text { Baik }\end{array}$ \\
\hline 3 & $40 \%$ hingga $55 \%$ & 1 & $\begin{array}{l}\text { Kategori } \\
\text { cukup }\end{array}$ \\
\hline 4 & $<40 \%$ & 0 & Kurang \\
\hline
\end{tabular}

Pengkategorian data evaluasi input indikator sarana dan prasarana didapat nilai dominan Sangat Baik dengan frekuensi 4. Hasil evaluasi penataan program pembelajaran PJOK berbasis daring indikator sarana dan prasarana adalah"Sangat Baik".

Evaluasi implementasi program dilakukan untuk mempelajari apakah program sudah dilakukan sesuai dengan rencana. Indikator evaluasi ini adalah adalah penilaiaan proses persiapan dan pelaksanaan pembelajaran PJOK berbasis daring. 
Berdasarkan hasil angket yang diisikan oleh guru Kelas didapatkan data evaluasi proses tersebut di kategorikan berdasarkan interval nilai pada Tabel 9.

\section{Tabel 9.}

Pengkategorian

data evaluasi

proses

\begin{tabular}{|c|c|c|c|}
\hline No & $\begin{array}{c}\text { Interval } \\
\text { Perolehan Nilai }\end{array}$ & Frekuensi & Keterangan \\
\hline 1 & $76 \%$ hingga 100\% & 36 & Sangat Baik \\
\hline 2 & $56 \%$ hingga 75\% & 6 & $\begin{array}{c}\text { Standar } \\
\text { Baik }\end{array}$ \\
\hline 3 & $40 \%$ hingga 55\% & 0 & $\begin{array}{c}\text { Kategori } \\
\text { cukup }\end{array}$ \\
\hline 4 & $<40 \%$ & 0 & Kurang \\
\hline
\end{tabular}

Pengkategorian data evaluasi proses didapat nilai dominan Sangat Baik dengan frekuensi 36. Hasil evaluasi implementasi program pembelajaran PJOK berbasis daring adalah "Sangat Baik".

Evaluasi produk bertujuan untuk mengetahui apakah program telah tercapai dengan baik, dalam penelitian ini parameter yang ingin dilihat adalah tingkat pemahaman siswa dan motivasi belajar siswa. Evaluasi ini dapat dilihat dari hasil evaluasi produk. Motivasi belajar siswa diukur berdasarkan dua faktor motivasi, yaitu faktor intrinsik dan faktor ekstrinsik. Terdapat lima skala yang digunakan yaitu sangat rendah, rendah, sedang, tinggi, dan sangat tinggi. Rekapitulasi hasil pengukuran motivasi siswa ditunjukkan pada Tabel 10.

Tabel 10. Rekapitulasi Angket Motivasi

\begin{tabular}{|c|c|c|}
\hline Faktor & Kriteria & Jumlah Siswa \\
\hline \multirow{4}{*}{ Intrinsik } & Sangat Tinggi & 59 \\
\cline { 2 - 3 } & Tinggi & 24 \\
\cline { 2 - 3 } & Sedang & 0 \\
\cline { 2 - 3 } & Rendah & 0 \\
\cline { 2 - 3 } & Sangat Rendah & 0 \\
\hline \multirow{4}{*}{ Ekstrinsik } & Sangat Tinggi & 38 \\
\cline { 2 - 3 } & Tinggi & 45 \\
\cline { 2 - 3 } & Sedang & 0 \\
\cline { 2 - 3 } & Rendah & 0 \\
\cline { 2 - 3 } & Sangat Rendah & 0 \\
\hline
\end{tabular}

Motivasi siswa dalam pembelajaran mata pelajaran PJOK berbasis daring tergolong pada kategori baik. Hasil pengukuran ditemukan seluruh siswa memiliki motivasi yang tinggi pada faktor intrinsik dan faktor ekstrinsik.

Evaluasi tingkat pemahaman siswa dinilai melalui ketercapaian hasil belajar siswa berdasarkan nilai KKM yang telah ditetapkan. Selanjutnya dilakukan pengkategorian ketercapaian hasil belajar siswa pada mata pelajaran PJOK berdasarkan KKM yang telah ditetapkan. KKM di SD Negeri Betro adalah 70. Siswa yang belum mendapatkan nilai 70 , dinyatakan tidak lulus KKM. Berdasarkan dokumentasi nilai yang diisikan guru PJOK didapatkan data statistik deskriptif seperti Tabel 11.

Tabel 11. Data evaluasi produk indikator tingkat pemahaman siswa

\begin{tabular}{|c|l|c|}
\hline No. & \multicolumn{1}{|c|}{ Data } & Skor \\
\hline 1 & Nilai Minimum & 40,00 \\
\hline 2 & Nilai Maksimum & 100,00 \\
\hline 3 & Rata-rata & 73,59 \\
\hline 4 & Median & 76,00 \\
\hline 5 & Modus & 84,00 \\
\hline 6 & Standar Deviasi & 13,7 \\
\hline
\end{tabular}

Program Belajar Dari Rumah (BDR) merupakan program baru yang ditetapkan oleh pemerintah sejak terjadi pandemi Covid19 kepada seluruh jenjang pendidikan tak terkecuali SD Negeri Betro. Program BDR yang memanfaatkan pembelajaran jarak jauh berbasis daring adalah hal baru bagi sekolah ini. Untuk tercapainya hasil pembelajaran yang optimal pada setiap pembelajaran termasuk Pendidikan Jasmani Olahraga dan Kesehatan (PJOK) dibutuhkan perancangan, pelaksanakan, serta dukungan dari komponen yang mendukung.

Pembelajaran PJOK dapat terlaksana dengan baik ditentukan oleh beberapa unsur, antara lain: siswa, guru, metode, lingkungan pendukung, sarana prasarana, kurikulum ,tujuan, dan penilaian (Suryobroto, 2004). Pada penelitian ini keberhasilan pembelajaran PJOK dilakukan melalui proses evaluasi dengan metode CIPP (Context, Input, Process, Product). Kriteria keberhasilan hasil evaluasi penelitian ini dikategorikan dalam beberapa kelompok meliputi: Sangat Baik, Baik, Kategori Cukup dan Kurang. Hasil 
evaluasi yang diharapkan adalah interval nilai pada kategori "Baik" untuk masing-masing komponen.

Evaluasi perencanaan program mencakup masalah yang berkaitan dengan relevansi pembelajaran daring dengan Kurikulum 2013 dan Surat Edaran No.15 Tahun 2020. Evaluasi perencanaan program masuk dalam aspek context pada evaluasi. Pada aspek ini akan dilihat sejauh mana relevansi antara materi pembelajaran daring dengan visi dan misi sekolah, ketersediaan media pembelajaran, kesesuaian materi PJOK dengan Kompetensi Inti, Kompetensi Dasar dan sesuai dengan usia serta jenjang pendidikan peserta didik. Serta kaitannya dengan usaha pencegahan dan penyebaran penularan Covid-19 Program pembelajaran daring (e-learning) merupakan usaha untuk terus mendukung akses pendidikan dalam kasus penutupan sekolah secara sementara termasuk saat kondisi pandemi Covid-19 (WHO, 2020). Untuk melancarkan pembelajaran daring di SD Negeri Betro yang baru pertama kali dilakukan maka materi pembelajaran telah dipersiapkan sebelum pembelajaran dimulai.

Selain materi pembelajaran, sekolah juga membantu dalam pencegahan penularan dan penyebaran Covid-19 karena sebelum dan sesudah pembelajaran siswa-siswi selalu diingatkan tentang bahaya penyakit Covid- 19 dan cara menerapkan protokol kesehatan dengan cara 3M yakni selalu memakai masker, selalu menjaga jarak, dan selalu mencuci tangan dengan air yang mengalir serta selalu membawa handsinitizer.

Berdasarkan hasil evaluasi relevansi pembelajaran PJOK berbasi daring dengan kurikulum 2013 dan SE Kemendikbud No.15 Tahun 2020 masuk pada kategori Sangat Baik. Hasil tersebut menunjukkan materi pembelajaran sesesuai dengan kurikulum 2013, sehingga siswa dapat mempelajari materi ajar untuk pencapaian kemampuan dasar PJOK.

Evaluasi penataan program meliputi aspek yang berkaitan dengan kesesuain dan kecukupan sumber daya yang tersedia untuk mencapai pembelajaran daring yang baik. Evaluasi penataan program masuk dalam aspek input pada evaluasi. Aspek ini memiliki peran yang penting dalam keberhasilan pembelajaran daring, aspek tersebut meliputi : latar belakang guru PJOK dan keterlibatan siswa, serta sarana dan prasarana dalam mendukung keberlangsungan pembelajaran.

Pembelajaran daring adalah usaha pemerintah dalam pemenuhan hak peserta didik untuk mendapatkan layanan pendidikan selama darurat penyebaran Corona Virus Disease (Covid-19) (Kemendikbud, 2020). Agar pembelajaran dapat berjalan dengan baik SD Negeri Betro mendelegasikan guru produktif yang mengajar sesuai dengan jurusannya. Berdasarkan hasil evaluasi melalui wawancara maupun angket dapat diketahui bahwa keseluruhan guru PJOK memiliki latar belakang pendidikan Strata 1 (S1) lulusan Program Studi Pendidikan Kepelatihan Olahraga dari berbagai Universitas yang telah terakreditasi sehingga relevan dengan mata pelajaran PJOK yang diampu. Hal tersebut sesuai dengan Permendiknas Nomor 16 pada tahun 2007 tentang latar belakang pendidikan guru. Peraturan tersebut menjelaskan bahwa guru pada sekolah jenjang dasar menengah diwajibkan memiliki suatu kualifikasi dengan pendidikan minimal Diploma-4 (D-4) atau Strata-1 (S1) sesuai program studi yang berdasarkan pada mata pelajaran yang diampu, serta berasal dari program studi terkareditasi.

Aspek selanjutnya adalah keterlibatan siswa. Keterlibatan siswa merupakan faktor penting dari keberhasilan proses belajar siswa di sekolah (Fredricks, dkk, 2016). Keterlibatan murid dapat menunjang proses pembelajarannya sehingga dapat berlangsung dengan baik (Revee, 2012). Hasil penelitian menunjukkan bahwa kehadiran dan antusiasme siswa cukup tinggi selama proses pembelajaran daring. Meskipun masih ada siswa yang belum mengikuti pembalajaran daring. Berkaitan dengan hal tersebut SD Negeri Betro memiliki kebijakan dengan memberikan tugas setiap guru kelas untuk mendorong siswa agar lebih giat belajar. Secara keseluruhan pada evaluasi input untuk aspek latar belakang guru PJOK dan keterlibatan siswa dapat dikatakan seluruh guru PJOK di SD Negeri Betro memiliki latar belakang yang sesuai dan diketahui bahwa 
keterlibatan siswa dinilai aktif dalam kegiatan pembelajaran PJOK.

Sarana prasana sangat merupakan faktor penting dalam pembelajaran PJOK. Terpenuhinya sarana prasarana pembelajaran PJOK akan memberikan sumbangsih terhadap siswa agar memudahkan memahami materi pembelajaran (Gustian \& Tomoliyus, 2015). Dalam pelaksanaan pembelajaran jarak jauh berbasis daring, ada beberapa faktor sarana dan prasarana yang harus dikembangkan guna menjamin mutu proses dan hasil pembelajaran. Faktor-faktor tersebut, antara lain: materi pembelajaran yang bermutu tinggi, bantuan pembelajaran, sistem ujian yang memungkinkan untuk memverifikasi kemampuan siswa, dan sistem yang terpadu dan sinergis dengan memanfaatkan teknologi informasi dan komunikasi (Munir, 2009). Berbagai upaya telah dilakukan oleh SD Negeri Betro dalam rangka melancarkan pembelajaran berbasis daring melalui perancangan pembelajaran yang menarik, pemanfaatan teknologi, bantuan paket data untuk meringankan siswa hingga pembaruan informasi mengenai pencegahan penularan dan penyebaran Covid-19. Upaya ini dilakukan untuk tetap menjamin akses pendidikan bagi siswa sekaligus menjalankan tugas sekolah sebagai salah satu pemrakarsa penerapan protokol kesehatan.

Hasil evaluasi menunjukkan bahwa sarana dan prasarana mendapatkan nilai dominan sangat baik. Jika dianalisa berdasarkan hasil angket sarana dan prasarana PJOK di SD Negeri Betro, masih adanya sarana prasana yang kurang mendukung di antaranya kecukupan bantuan paket data yang dirasa masih kurang, peralatan olahraga yang dapat mendukung pembelajaran siswa di rumah dan referensi buku/jurnal online. Secara keseluruhan sarana dan prasarana PJOK di SD Negeri Betro masuk dalam kategori baik, namun masih ada cukup banyak hal yang membutuhkan peningkatan dalam indikator sarana dan prasarana.

Evaluasi implementasi program mencakup proses persiapan dan pelaksanaan pembelaran PJOK. Evaluasi ini masuk dalam aspek proses. Proses pembelajaran akan lebih terarah jika disertai strategi pembelajaran yang jelas, sehingga tujuan dari pembelajaran dapat tercapai optimal (Wina, 2009). Proses persiapan dan pelaksanaan pembelajaran PJOK berbasis daring terdiri dari persiapan Guru dalam menghadapi pembelajaran daring, pelaksanaan pembelajaran PJOK meliputi kegiatan kegiatan pendahuluan, kegiatan inti, aktivitas siswa saat pembelajaran daring melalui panggilan video, dan penutup. Persiapan guru PJOK di SD Negeri Betro meliputi penyesuaian pembelajaran berbasis daring dengan program tahunan atau disebut juga dengan prota dan promes, pembuatan media pembelajaran yang kreatif serta menyenangkan agar pembelajaran menjadi lebih hidup sehingga siswa tidak mudah bosan dan pembelajaran menjadi menyenangkan. Selama proses pembelajaran daring berlangsung guru PJOK tetap berpenampilan rapi dan selalu menerapkan protokol kesehatan. Protokol kesehatan terus dilakukan agar menjadi contoh bagi siswa untuk selalu menerapkan protokol kesehatan dimanapun tempatnya guna mencegah penularan dan memutus rantai penyebaran virus Covid-19. Evaluasi hasil adalah evaluasi yang digunakan untuk mengukur keberhasilan pembelajaran daring. Aspek yang dinilai mencakup motivasi belajar siswa dan tingkat pemahaman siswa. Evaluasi ini termasuk dalam aspek produk. Motivasi belajar menjadi salah satu faktor penyebab keberhasilan suatu program pendidikan. Motivasi merupakan dorongan dari dalam maupun luar yang menyebabkan seseorang terdorong untuk melakukan aktivitas tertentu dalam rangka memenuhi kebutuhan sehingga dapat mendorong dirinya untuk lebih giat dan mencapai hasil yang maksimal.

Evaluasi produk indikator motivasi belajar PJOK menunjukkan hasil dominan pada kategori "Sangat Tinggi". Berdasarkan hasil wawancara diketahui bahwa antusiasme siswa terhadap pembelajaran daring sangat baik. Namun, seiring berjalannya waktu suasana belajar tatap muka lebih diharapkan siswa karena terbatasnya interaksi pada proses pembelajaran daring serta dukungan fasilitas internet yang kurang memadai. Faktor yang mendorong timbulnya motivasi belajar dibagi menjadi faktor internal dan faktor eksternal. Motivasi belajar siswa SD Negeri Betro yang berasal dari dalam diri siswa (intrinsik) 
Jurnal Ilmiah Mandala Education

http://ejournal.mandalanursa.org/index.php/JIME/index terakreditasi Peringkat 4 (No. SK: 36/E/KPT/2019) memiliki nilai dominan yang masuk dalam kategori "Sangat tinggi". Dari 83 siswa sebanyak 59 siswa mempunyai motivasi intrinsik sangat tinggi dan 24 siswa dengan motivasi intrinsik tinggi. Faktor intrinsik merupakan dorongan dari dalam diri siswa dalam mengikuti pembelajaran PJOK berbasis daring. Dorongan tersebut dapat berupa dorongan dalam diri berupa kesehatan, minat, bakat dan perhatian. Berdasarkan hasil evaluasi maka dapat ditarik kesimpulan bahwa siswa memiliki kemauan dan kesadaran dari diri sendiri untuk secara aktif mengikuti pembelajaran PJOK berbasis daring. Motivasi belajar siswa SD Negeri Betro yang berasal dari luar diri siswa (ekstrinsik) memiliki nilai dominan yang masuk dalam kategori "Tinggi”. Dari 83 siswa sebanyak 38 siswa mempunyai motivasi ekstrinsik sangat tinggi dan 45 siswa dengan motivasi ekstrinsik tinggi. Meskipun rataan motivasi ekstrinsik siswa dalam kategori sangat tinggi, namun jumlah dominan berada pada kategori tinggi. Faktor ekstrinsik merupakan dorongan yang berasal dari luar diri siswa dalam mengikuti pembelajaran PJOK berbasis daring. Motivasi ekstrinsik merupakan faktor penting dalam pembelajaran, karena tidak semua proses dan/atau materi pelajaran merupakan minat atau bakat siswa dan belum munculnya kesadaran siswa akan pentingnya bahan pelajaran yang disampaikan oleh guru. Dalam keadaan tersebut siswa membutuhkan stimulus/dorongan untuk menciptakan motivasi belajar siswa. Dorongan dari luar dapat berupa metode mengajar yang menarik, alat pelajaran yang inovatif, kondisi lingkungan yang menyenangkan. Rendahnya motivasi ekstrinsik dibandingkan dengan motivasi ekstrinsik sejalan dengan informasi yang didapt melalui wawancara bahwa siswa mulai merasa keberatan atas terbatasnya fasilitas yakni pengadaan paket data selama proses pembelajaran daring.

Tingkat pemahaman siswa dilihat dari perolehan hasil prestasi belajar. Hasil prestasi belajar pada mata pembelajaran PJOK diperoleh dari data dokumentasi oleh guru PJOK. Evaluasi data dokumentasi PJOK didapatkan nilai rerata sebesar 73.59 yang masuk dalam "Kategori Cukup". SD Negeri
Vol. 7. No. 1. Januari 2021

p-ISSN: 2442-9511 e-ISSN: 2656-5862

Betro menetapkan Standar Ketuntasan Belajar (SKBM) atau Kriteria Ketuntasan Minimal (KKM) pada mata pelajaran PJOK pada kelas IV - VI adalah 70. Hasil tersebut sesuai dengan hasil wawancara yang telah dilakukan. Bahwasannya guru sudah berusaha semaksimal mungkin untuk menciptakan pembelajaran yang layak demi mencerdaskan siswa di masa pandemi. Namun pihak sekolah tetap mengharapkan peran dari orang tua agar selalu mengawasi dan mendukung penuh pembelajaran daring agar tercapai pembelajaran berjalan secara maksimal dan pemahaman siswa semakin berkembang. Faktor yang mempengaruhi hasil prestasi belajar terbagi menjadi dua yaitu, faktor internal dan faktor eksternal. Faktor internal merujuk dari dalam diri siswa dan faktor eksternal merujuk dari pengaruh luar seperti sarana prasarana dan sebagainya termasuk di dalamnya adalah kesiapan siswa untuk keikutsertaan selama pembelajaran (Slameto, 2003).

\section{KESIMPULAN}

Hasil evaluasi menunjukkan bahwa : (1) aspek perencanaan program dengan indikator relevansi kurikulum 2013 dan SE Kemendikbud No. 15 Tahun 2020 dengan pembelajaran di sekolah pada standar kategori sangat baik; (2) aspek penataan program dengan indikator latar belakang guru PJOK dan keterlibatan siswa, serta sarana dan prasarana pada standar kategori sangat baik; (3) aspek implementasi program dengan indikator persiapan dan pelaksanaan pembelajaran PJOK pada standar kategori sangat baik; dan (4) aspek hasil program indikator motivasi belajar menunjukkan motivasi belajar siswa faktor intrinsik dan ekstrinsik menunjukkan kriteria sangat tinggi dan tingkat pemahaman siswa yang dilihat dari hasil belajar siswa menunjukkan nilai lulus KKM. Masih diperlukan perbaikan dalam beberapa aspek agar pembelajaran dapat berjalan dan mendapatkan hasil yang optimal. Program Belajar Dari Rumah dengan metode Pembelajaran Jarak Jauh berbasis Daring merupakan salah satu solusi dalam pemenuhan akses pendidikan yang layak bagi siswa selama masa pandemic. 


\section{REFERENSI}

Arikunto, S. (1998). Prosedur Penilaian. Jakarta: Rineka Cipta.

Chen, P. C., Mao, L., Nassis, G. P., \& Harmer, P. (2020). Returning Chinese school-aged children and adolescents to physical activity. Journal of Sport and Health Science. 1-3.

Darsono. (2000). Belajar dan Pembelajaran. Semarang : IKIP Press. Daryanto. (2008). Evaluasi Pendidikan. Jakarta: Rineka Cipta.

Desmita. (2012). Psikologi Perkembangan Peserta Didik. Bandung: Rosdakarya.

Dewi, N. N. S. (2018). Analisis Pengaruh Tingkat Persepsi Kurikulum 2013 (K13) terhadap Kinerja Guru PKN pada Tingkat Satuan Pendidikan SD SMA di UPT Dinas Pendidikan wilayah Denpasar Timur. Jurnal Ilmu Manajemen. 2 (1).

Emda, Amna (2017). Kedudukan Motivasi Belajar Siswa dalam Pembelajaran. Lantanida Journal. 5 (2), 93-196.

Fredricks, J. A., Filsecker, M \& Lawson, M.A. (2016). Student engagement, context, and adjustment: Addressin definitional, measurement, and methodological issues. Learning and Instruction Journal. 43, 1-4.

Gulo, W. (2010). Metodologi Penelitian. Jakarta: Grasindo.

Gustian, U., \& Tomoliyus, T. (2015). Pengembangan model pembelajaran integratif berbasis aktivitas jasmani untuk taman kanak-kanak. Jurnal Keolahragaan. 3(2), 241-251.

Hamalik, O. (2010). Belajar dan faktor-faktor yang mempengaruhinya. Jakarta: Rineka Cipta.

Hamzah B. Uno. (2011). Teori Motivasi dan Pengukurannya: Analisis di Bidang Pendidikan. Jakarta: Bumi aksara.

Jalil, Aria (1994). Pendidikan Jarak Jauh. Jurnal Ilmu Pendidikan. 1(1), 22-43. Jatmika H. (2005). Pemanfaatan Media Visual dalam Menunjang Pembelajaran

Pendidikan Jasmani di Sekolah Dasar. Jurnal Pendidikan Jasmani Indonesia.

Kemendikbud. (2006). PeraturanMenteri Pendidikan Nasional Nomor 22 Tahun 2006 tentang Standar Isi. Jakarta:
Sekretariat Negara.

Kemendikbud. (2013). Peraturan Menteri

Pendidikan dan Kebudayaan Nomor 70

Tahun 2013 tentang tentang Kerangka

Dasar dan Struktur Kurikulum. Jakarta:

Sekretariat Negara.

Kemendikbud. (2014). Implementasi

Kurikulum 2013. Jakarta: Kementrian

Pendidikan dan Kebudayaan RI.

Jakarta: Sekretariat Negara.

Kemendikbud. (2014). Peraturan Menteri Pendidikan dan Kebudayaan Nomor 119 Tahun 2014 tentang Penyelenggaraan Pendidikan Jarak Jauh Jenjang Pendidikan Dasar dan Menengah. Jakarta: Sekretariat Negara.

Kemendikbud. (2020). Surat Edaran Nomor

15 Tahun 2020 tentang Pedoman Penyelenggaraan Belajar Dari Rumah dalam Masa Darurat Penyebaran Corona Yirus Disease (Covid-19). Jakarta: Sekretariat Negara.

Kemendikbud. (2020). Surat Edaran Nomor 4 Tahun 2020 tentang Pelaksanaan Kebijakan Pendidikan dalam Masa Darurat Penyebaran Coronavirus Disease (Covid- 1 9). Jakarta: Sekretariat Negara.

Latifa, Umi. (2017). Aspek Perkembangan pada Anak Sekolah Dasar: Masalah dan Perkembanganna. Jurnal Academica. 1(2), 185 - 195.

Lutan, Rusli. (2001). Asas-asas Pendidikan Jasmani. Jakarta : Depdiknas.

Munir. (2009). Pembelajaran Jarak Jauh berbasis Teknologi Informasi dan Kominukasi. Bandung : Penerbit Alfabeta.

Papalia, Diane, E., Wendkos, Sally. (1986). Human Development. New York : McGraw-Hill.

Pemerintah Indonesia. (2005). Peraturan Pemerintah Nomor 19 Tahun 2005. Jakarta: Sekretariat Negara.

Pemerintah Indonesia. (2005). Undang Undang No 3 Tahun 2005 tentang Sistem Keolahragaan Nasional. Lembaran Negara RI Tahun 2005, No 3. Jakarta: Sekretariat Negara.

Pemerintah Indonesia. 2003. Undang Undang No 20 Tahun 2003 tentang Sistem Pendidikan Nasional. Lembaran 
Negara RI Tahun 2003, No 20. Jakarta:

Sekretariat Negara.

Purwanto. (2013). Evaluasi hasil belajar.Yogyakarta: Pustaka Pelajar.

Rahyubi, Heri. (2012). Teori-teori Belajar dan Aplikasi Pembelajaran Motorik. Bandung : Nusa Media.

Revee, Johnmashall. 2012. Handbook of Research on Student Engagement. Journal of Educational. 149-172.

Sanjaya, Wina. (2011). Strategi Pembelajaran Berorientasi Standar Proses Pendidikan. Jakarta: Kencana.

Sardiman, A.M. (2006). Interaksi dan Motivasi Belajar-Mengajar. Jakarta: Raja Grafindo Persada.

Sari, H. I. P. (2018). Pengaruh Kurikulum 2013 (K13) terhadap Kinerja Pemuda dalam Sistem Pengajaran di MI Al Fithrah Surabaya (Tesis master). Pascasarjana Universitas Islam Negeri Sunan Ampel Surabaya.

Simamora, A,H., Sudarma, I. K. (2017). Analisis Perangkat Pembelajaran Kurikulum 2013 di Sekolah Dasar. Journal of Education Technology. 1(2), 149-155.

Slameto. (2003). Belajar dan faktor-faktor yang mempengaruhinya. Jakarta: Rineka Cipta.

Sriundy, I M. (2015). Metodologi Penelitian. Surabaya: Unesa University Press.

Sudijono, Anas. (2009). Pengantar evaluasi pendidikan. Jakarta: Rajagrafindo. Sugiyono. (2010). Metode penelitian pendidikan. Bandung: CV Alfabeta.

Sugiyono. (2013). Metode penelitian manajemen. Bandung: CV Alfabeta.

Suharsimi Arikunto. (2006). Prosedur penelitian, suatu pendekatan praktik. Jakarta : Rineka Cipta.

Sukintaka.(1992). Teori Pendidikan Jasmani. Solo: Esa Grafika.

Suryobroto, AS. (2004). Sarana dan Prasarana Pendidikan Jasmani. Universitas Negeri Yogyakarta : Fakultas Ilmu Keolahragaan.

Warju, W. (2016). Educational Program Evaluation using CIPP Model. Innovation of Vocational Technology Education, Vol. 12(1).
p-ISSN: 2442-9511 e-ISSN: 2656-5862

WHO. (2020). Key Messages and Actions for COVID-19 Prevention and Control in Schools. Education UNICEF NYHQ

Widoyoko, EP. (2014). Penilaian Hasil Pembelajaran di Sekolah. Yogyakarta: Pustaka Pelajar.

Winkel, A. F., Gillespie, C., Hiruma, M. T., Goepfert, A. R., Zabar, S., \& Szyld, D. (2014). Test of integrated professional skills: objective structured clinical examination/simulation hybrid assessment of obstetricsgynecology residents' skill integration. Journal of graduate medical education. 6(1), 117122.

Yunus, Muhammad.(2019). Pelatihan Kurikulum 2013 untuk Guru SD di SD Islam Al Fatih Kecamatan Alalak Kabupaten Barito Kuala Kalimantan Selatan. Jurnal Pengabdian Masyarakat Ilmu Keguruan dan Pendidikan. 